International Studies Perspectives (2019) 0, 1-43

\title{
Teaching Religion and International Relations: Disciplinary, Pedagogical and Personal Reflections
}

\author{
GREGORIO BETTIZA \\ University of Exeter \\ DEINA ABDELKADER \\ University of Massachusetts Lowell and Harvard University \\ DAVID T. BUCKLEY \\ University of Louisville \\ JOCELYNE CESARI \\ University of Birmingham and Georgetown University \\ JEFFREY HAYNES \\ London Metropolitan University \\ NUKHET SANDAL \\ Ohio University \\ AND \\ GIORGIO SHANI \\ International Christian University
}

\begin{abstract}
The study of religion and international religions has witnessed an exponential growth in recent decades. Courses and programs exploring the complex entanglements between faith and global politics have likewise mushroomed around the world. Despite this ferment, reflections on teaching religion and international relations have so far lagged behind. This forum seeks to remedy this general silence. It brings together a diverse range of scholars from a multiplicity of national, religious, methodological, and theoretical backgrounds who teach across a variety of different geographical settings including North America, Europe, and East Asia. Contributors reflect on three broad themes. First, how do we engage with the contested character of religion as a category of analysis and practice, and with the multidisciplinary nature of its study? Second, how does the context within which we operate - be it geographical, cultural, institutional, or historical - influence and shape who, what, and how we teach? Third, how do we address the important and, at times, contentious personal and ethical challenges that our research and teaching on religion and politics inevitably raises in the classroom?
\end{abstract}

Resumen: El estudio de la religión y de las religiones internacionales ha sido testigo de un crecimiento exponencial en las últimas décadas. De igual manera, los cursos y programas en los que se exploran los entrelazamientos entre la fe y la política mundial han proliferado en todo el mundo. Pese a esta agitación, las reflexiones sobre la enseñanza de la religión y las relaciones internacionales han quedado, hasta el momento, rezagadas. En este foro se apunta a poner fin a este silencio generalizado. En él, se reúne a diferentes académicos de una gran variedad de contextos nacionales, religiosos, metodológicos y teóricos que enseñan en distintos entornos geográficos, incluidos América del Norte, Europa y Asia del este. Los colaboradores reflexionan sobre tres grandes ejes temáticos. En primer lugar, ¿cómo interactuamos con el controvertido 
carácter de la religión como categoría de análisis y práctica, y con la naturaleza multidisciplinaria de su estudio? En segundo lugar, ¿de qué manera el contexto - ya sea geográfico, cultural, institucional o histórico - en el cual operamos influye y moldea a quiénes, qué y cómo enseñamos? En tercer lugar, ¿cómo abordamos los importantes y, en ocasiones, contenciosos desafíos personales y éticos que nuestra investigación y enseñanza sobre religión y política inevitablemente plantean en el aula?

Extrait: L'étude de la religion et des relations internationales a connu une croissance exponentielle au cours des dernières décennies. Des cours et programmes décortiquant les relations complexes entre la foi et la politique internationale ont également proliféré dans le monde entier. Malgré cette effervescence, les réflexions sur l'enseignement de la religion et des relations internationales se font toujours attendre. Cette tribune cherche à répondre à ce silence général. Elle réunit plusieurs spécialistes de nationalité, religion, méthode et théorie différentes qui enseignent dans une grande variété de pays en Amérique du nord, Europe et Asie de l'est. Les contributeurs réfléchissent sur trois grands thèmes. Premièrement, comment abordonsnous le caractère contesté de la religion en tant que catégorie d'analyse et de pratique ainsi que la nature pluridisciplinaire de son étude? Deuxièmement, comment le contexte dans lequel nous agissons - qu'il soit géographique, culturel, institutionnel ou historique - influence et façonne les personnes à qui nous enseignons, la matière que nous enseignons et notre méthode pédagogique? Troisièmement, comment abordons-nous les problématiques importantes et parfois contestées, personnelles et éthiques que nos recherches et notre enseignement sur la religion et la politique ne manquent pas de soulever chez nos étudiants?

Keywords: religion, international relations, global politics, teaching, pedagogy

\section{Articles in This Forum}

Introduction

Gregorio Bettiza

Teaching Islam and International Relations

Deina Abdelkader

Context and the Classroom: Teaching Religion and World Politics

David T. Buckley

Teaching Religion and International Politics: Beyond Theology and Belief

Jocelyne Cesari

Teaching Religion and International Relations in London:

Managing Productively Class and World Diversity

Jeffrey Haynes

Religion and Politics in the Global Classroom 


\section{Nukhet Sandal}

Teaching Religion in International Relations outside the West

Giorgio Shani

Conclusion: Five Challenges to Teaching Religion and International Relations

Gregorio Bettiza

\section{Introduction}

GREGORIO BETTIZA

University of Exeter

With the onward march of modernity, the world was supposed to become ineluctably secular-or so, over the past two centuries, the vast majority of social scientists assumed, if not even hoped. Yet the world does not seem to have followed the teleological path towards modernity that secularization theory had assigned to it and which secularist ideologies had dreamed of. Various forms of religious fundamentalism, terrorism, nationalism, and identity politics have emerged across most traditions and regions of the world breeding new forms of intolerance and violence. In parallel, religious actors and communities are at the forefront of many of the most pressing battles against poverty, inequality, discrimination, and climate change in the context of a global capitalist system that appears to have spun out of control. States are ever more consistently seeking to promote international religious freedom, support interreligious dialogues, and engage with faithbased actors in order to solve many of the world's most pressing issues and intractable conflicts.

In an international system where religions seem to be persisting and thriving in multiple and complex ways, and their powerful entanglements with social and political dynamics at the local and global levels are being felt by millions of people everywhere every day, social scientists have become increasingly disenchanted with theories positing humanity's progressive disenchantment. Scrambling to make sense of our present condition, scholars have invariably defined it in a plethora of ways: "God's revenge" (Kepel 1994), the "desecularization" of the world (Berger 1999), the 
emergence of "multiple modernities" (Eisenstadt 2000), a supposed "clash of civilizations" (Huntington 1996), or the dawn of a "post-secular" age (Habermas 2006).

It is within this social, political, and intellectual context that over the past decades, the discipline of international relations (IR) ${ }^{1}$ has witnessed an exponential growth in research on religion. ${ }^{2}$ Considerable soul searching and reflection has taken place over the years as to why international relations has tended to empirically neglect and under-theorize religion, how best it should approach the subject, and whether faith can seamlessly be integrated within international relations' existing theoretical and methodological frameworks. Or, alternatively, whether a serious engagement with the divine and the sacred requires the complete re-thinking of the philosophical and normative foundations on which the discipline rests (Kubálková 2000; Philpott 2002; Hatzopoulos and Petito 2003; Thomas 2005; Haynes 2006; Hurd 2008; Snyder 2011; Toft, Philpott, and Shah 2011; Sandal and Fox 2013).

Against this backdrop, undergraduate courses and Master's programs dedicated to the study of religion in comparative and global politics have been proliferating around the world. Yet, little reflection and guidance exists to this day in the literature on how to navigate the complex waters of approaching this subject in the classroom. As Sandal in her contribution to this Forum finds, a Google search for "teaching religion and international studies" or "teaching religion and global politics," yields no results, while a search for "teaching religion and international politics" or "teaching religion and international relations" will bring up only three results each. ${ }^{3}$

The present forum, which emerges from a roundtable organized at the International Studies Association Annual Convention in Baltimore in 2017, seeks to remedy this general silence by bringing together a canopy of experiences. These include those of established and emerging scholars in the field of religion and political science/international relations from a multiplicity of national, religious, methodological, and theoretical backgrounds, who teach undergraduate and postgraduate classes across a variety of geographical settings including North America, Europe, and East Asia. The type of courses being taught also varies, some approach religion from an

\footnotetext{
${ }^{1}$ International relations is hereby understood not exclusively as a sub-field of political science concerned with (peaceful or violent) interactions among states, but more broadly as a field attentive to a multiplicity of transnational, international and global actors, processes, and relations.

${ }^{2}$ For a useful overview of the field of religion and international relations, see Bettiza (2016).

${ }^{3}$ This dearth of reflection does not afflict only international relations, but multiple other disciplines. Quite notable are a series of recent "conversations" around teaching that The Immanent Frame, a leading blog on religion in the social sciences and humanities, has begun to publish (The Immanent Frame 2017; 2018).
} 
international relations/global politics perspective while others from a more comparative one, some focus on religion in general while others on one tradition in particular-especially Islam.

The pedagogical challenges of teaching religion and international relations are many, as one can expect. Contributors reflect on three broad themes. The first of these revolves around the category of and knowledge produced about religion. The very subject and object that we teach in our classes, i.e. religion, is itself a highly contested concept. In what ways, therefore, do we as teachers go about addressing, if at all, the continued and at times acrimonious debates about what constitutes "religion" (and, potentially, also its antonym the "secular")? Moreover, this very same subject and object of inquiry requires bridging multiple disciplinary boundaries, including bringing into our classes insights from sociologists, anthropologists, philosophers, theologians, and religious studies scholars who have thought longer and harder about religion than political scientists/international relations scholars have. This inevitably begets the question: how do we go about navigating the challenges of interdisciplinarity in the context of a disciplinary age?

A second set of issues pertains to how the context within which we operate-be it geographical, cultural, institutional, or historical - influences and shapes how, what, and who we teach. In particular does it matter whether we teach in North America, Europe, or Asia; in a mostly secular or religious cultural context; in a research-intensive or teaching-intensive university; or before and after September 11, 2001? If so, in what ways does context influence our practices, and how do we approach our students differently depending on the multiple different contexts we simultaneously inhabit?

A third set of issues revolve around a range of personal and ethical considerations that the topic of religion raises. Etiquette notoriously suggests that one should avoid talking about religion and politics in polite company. The assumption, not unfounded, is that these subjects are too intimate, emotionally charged, and contentious to be discussed in public settings without incurring into controversy and possibly conflict. Scholars, like those of us in this Forum who teach both religion and politics (broadly understood), however, inevitably do away with such conventions in the classroom. As a result, a number of conundrums emerge: How far, for example, should we seek to appear objective and neutral, or actually reveal our own subject-positions-especially religious/non-religious identities and beliefs - to students? How do we approach political and religious diversity in the class? Following on this, how do we manage potential tensions that may arise when treating particularly sensitive issues and debates, including the Israeli-Palestinian 
conflict, the clash of civilizations, or religious freedom? Although a key aim of education is to develop students' ability to think critically, there are often some intellectual boundaries thatimplicitly or explicitly_ get enforced in the classroom around what constitutes (in)appropriate discourse. Should we be setting any boundaries and, if so, which ones?

A multiplicity of different perspectives along with important areas of overlap emerge from this forum, where each contributor reflects in a frank and thoughtful manner upon his/her own experience. Abdelkader, for instance, identifies a number of "quagmires"-rooted in particular ideological and methodological assumptions - that she seeks to explicitly overcome when teaching courses on Islam and international relations, including the tendency to singularly approach Islam as an irrational and violent force. Buckley's contribution, instead, explores how the university and geographical context within which he teaches, not just particular intellectual traditions, considerably impact what his students think and how he approaches the classroom. Cesari highlights the importance of bringing the wealth of knowledge from religious studies into her political science classroom and moves beyond the propensity to approach religion as a rigid, decontextualized, and de-historicized, set of beliefs.

A key concern for Haynes, who teaches in a cosmopolitan city like London, is to find ways to manage productively the world diversity - including religious - that he and his students encounter in the micro-cosmos of the class. Sandal gives an insightful panoramic of her own "global" approach to teaching religion, at the core of which lies a profoundly self-reflexive attitude centered on making her own identity and experiences explicit to students. Last, but certainly not least, Shani reflects in important ways on what it means to teach religion "outside the West" and, I would add, beyond a generalized focus on the Abrahamic faiths which marks most other interventions. In a concluding piece, I seek to bring these multiple voices together by highlighting five broad challenges to teaching religion in political science/international relations that emerge from this forum as a whole.

During his tenure as President Barack Obama's Secretary of State, John Kerry was fond of saying that if he were to go back to college he would probably major in comparative religions. A sense that faith matters today in world affairs more so than ever, despite multiple (premature) pronouncements of its death, makes the study of religion and international relations especially important at this historical juncture. This forum emerged precisely in response to these pressing needs. Rather than seeking to provide any definitive answers, though, we hope to stimulate a lively discussion about this complex subject. Let the conversation begin! 


\section{References}

AbDelKader, Deina Ali. 2011. Islamic Activists: The Anti-Enlightenment Democrats. London: Pluto Press.

ACHARYA, AMITAV. 2014. "Global International Relations (IR) and Regional Worlds: A New Agenda for International Studies.” International Studies Quarterly 58 (4): 647-659.

AdCOCK, ROBERT, AND DAVID COLLIER. 2001. "Measurement Validity: A Shared Standard for Qualitative and Quantitative Research.” American Political Science Review 95 (3): 529-546.

ApPLEBy, R. SCOTT. 2000. The Ambivalence of the Sacred: Religion, Violence, and Reconciliation. Lanham, MD: Rowman \& Littlefield Publishers.

ARMSTRONG, KAREN. 2015. Fields of Blood: Religion and the History of Violence. London: Vintage.

ASAD, TALAL. 2003. Formations of the Secular: Christianity, Islam, Modernity, Cultural Memory in the Present. Stanford, CA: Stanford University Press.

-----. 2011. "Thinking about Religion, Belief, and Politics.” In The Cambridge Companion to Religious Studies, edited by Robert A. Orsi, 36-57. Cambridge: Cambridge University Press.

Asal, Victor, And Elizabeth L. Blake. 2006. "Creating Simulations for Political Science Education.” Journal of Political Science Education 2 (1): 1-18.

BANCHOFF, ThOMAS. 2005. "Path Dependence and Value-driven Issues: The Comparative Politics of Stem Cell Research." World Politics 57 (2): 200-230.

BARBER, BENJAMin R., AND RICHARD BATTISTONI. 1993. "A Season of Service: Introducing Service Learning Into the Liberal Arts Curriculum." PS: Political Science \& Politics 26 (2): 235240.

Baylis, John, Steve Smith, And PAtricia OWens. 2017. The Globalization of World Politics: an Introduction to International Relations, 7th ed. Oxford: Oxford University Press.

Berger, Peter L., ED. 1999. The Desecularization of the World: Resurgent Religion and World Politics. Grand Rapids, MI: Ethics and Public Policy Center, Eermans Publishing.

Berger, Peter L. 2011. Adventures of an Accidental Sociologist: How to Explain the World Without Becoming a Bore. Amherst, New York: Prometheus Books. 
BettizA, GRegorio. 2016. "Religion and International Relations." In Oxford Bibliographies: International Relations, edited by Patrick James. Oxford: Oxford University Press. Accessed March 20, 2019. http://www.oxfordbibliographies.com/view/document/obo-9780199743292/obo9780199743292-0172.xml? rskey $=\mathrm{oX}$ fovI\&result $=123$.

BETTIZA, GREGORIO, AND FILIPPO DIONIGI. 2015. "How do Religious Norms Diffuse? Institutional Translation and International Change in a Postsecular World Society." European Journal of International Relations 21 (3): 621-646.

Bromley, Simon. 1997. "Middle East Exceptionalism." In Democratization, edited by David Potter, 321-330. Cambridge: Polity.

Brooke, Steven, And NeIL Ketchley. 2018. "Social and Institutional Origins of Political Islam." American Political Science Review 112 (2): 376-394.

BuCKLeY, DAVID T. 2015. "Beyond the Secularism Trap: Religion, Political Institutions, and Democratic Commitments." Comparative Politics 47 (4): 439-458.

CASAnOva, JosÉ. 1994. Public Religions in the Modern World. Chicago: University of Chicago Press.

CaVanaugh, William T. 2009. The Myth of Religious Violence: Secular Ideology and the Roots of Modern Conflict. Oxford: Oxford University Press.

Cesari, Jocelyne. 2014. The Awakening of Muslim Democracy: Religion, Modernity, and the State. Cambridge: Cambridge University Press.

-----. 2018a. "Unexpected Convergences: Religious Nationalism in Israel and Turkey.” Religions 9 (11): 334 .

------. 2018b. What is Political Islam? Boulder: Lynne Rienner.

CESARI, Jocelyne, AND JONATHAN FoX. 2016. "Institutional Relations Rather Than Clashes of Civilizations: When and How Is Religion Compatible with Democracy?” International Political Sociology 10 (3): 241-257.

Chakrabarty, DiPesh. 2000. Provincializing Europe: Postcolonial Thought and Historical Difference. Princeton, NJ: Princeton University Press.

Chiozza, Giacomo. 2002. "Is There a Clash of Civilizations? Evidence from Patterns of International Conflict Involvement, 1946-97.” Journal of Peace Research 39 (6): 711-734. 
A COMMON WORD. 2007. "Introduction to a Common Word between Us and You." Accessed June 4, 2019. http://www.acommonword.com.

COX, ROBERT. 1981. "Social Forces, States and World Orders: Beyond International Relations Theory.” Millennium-Journal of International Studies 10 (2): 126-155.

DARLINGTON, SuSAn M. 2012. Ordination of a Tree, The: The Thai Buddhist Environmental Movement. Albany: State University of New York Press.

DAVIE, Grace, AND DANiÈle Hervieu-LÉGER. 1996. Identités religieuses en Europe. Paris: La Découverte.

DERRIDA, JACQUES. 1998. "Faith and Knowledge: the Two Sources of 'Religion' and the Limits of Reason Alone." In Religion, edited by Jacques Derrida and Gianni Vattimo, 1-79. Stanford: Stanford University Press.

DJuPe, PaUl, AND BRIAn CALFANO. 2013. God Talk: Experimenting with the Religious Causes of Public Opinion. Philadelphia, PA: Temple University Press.

DobBelaere, KAREL. 2002. Secularization: An Analysis at Three Levels. Frankfurt am Main: Peter Lang.

Edkins, Jenny, And MajA Zehfuss, EDS. 2014. Global Politics: A New Introduction to International Relations, 2nd ed. Abingdon: Routledge.

EISEnStadT, SHMUEL N. 2000. “Multiple Modernities.” Daedalus 129 (1): 1-29.

ENDO, SHUSAKU. 1969. Silence. Translated by William Johnson. London: Peter Owen.

ESPOSITO, JOHN L., DARRELl J. FASCHING, AND TODD LEWIS. 2007. Religion and Globalization: World Religions in Historical Perspective. New York: Oxford University Press.

Euben, RoXANnE L. 1999. Enemy in The Mirror: Islamic Fundamentalism and The Limits of Modern Rationalism: A Work of Comparative Political Theory. Princeton, NJ: Princeton University Press.

FollmanN, Jose IVO. 2017. "Brazil, Catholic Religion, and Education: Challenges and Prospects." International Studies in Catholic Education 9 (1): 76-88. 
FOX, JONATHAN. 2001. "Religion as An Overlooked Element of International Relations." The International Studies Review 3 (3): 53-73.

-----. 2002. "Ethnic Minorities and the Clash of Civilizations: A Quantitative Analysis of Huntington's Thesis." British Journal of Political Science 32 (3): 415-434.

GEARON, LiAM. 2013. "The Counter Terrorist Classroom: Religion, Education, and Security." Religious Education 108 (2): 129-147.

Goertz, Gary. 2006. Social Science Concepts: A User's Guide. Princeton, NJ: Princeton University Press.

GOPIN, MARK. 2012. "Religion as Destroyer and Creator of Peace: A Postmortem on Failed Peace Process." In Religion and Foreign Affairs: Essential Readings, edited by Dennis Hoover and Douglas Johnston, 271-280. Waco: Baylor University Press.

GRIFFITHS, PAUl J. 2000. “The Very Idea of Religion.” First Things 103: 30-35. Accessed March 20, 2019. https://www.firstthings.com/article/2000/05/the-very-idea-of-religion.

HABermas, JÜRGEN. 2006. "Religion in the Public Sphere.” European Journal of Philosophy 14 (1): $1-25$.

HABERMAS, JÜRGEN, AND JOSEPH RATZINGER. 2006. Dialectics of Secularization: On Reason and Religion. San Francisco: Ignatius Press.

HAfEZ, KaI. 2010. Radicalism and Political Reform in the Islamic and Western Worlds. Cambridge: Cambridge University Press.

Hatzopoulos, PaVlos, AND FABio Petito, EDS. 2003. Religion in International Relations: the Return from Exile, 1st ed. Basingstoke: Palgrave Macmillan.

HAYNES, JEFFREY. 1998. Religion in Global Politics. Harlow: Longman.

-----. 2006. "Religion and International Relations in the 21st Century: Conflict or Co-operation?" Third World Quarterly 27 (3): 535-541.

------. 2007. An Introduction to International Relations and Religion, 1st ed. London: Pearson.

HAynes, JefFrey, Peter Hough, Shahin MAlik, AND Lloyd PetTiford. 2017. World Politics: International Relations and Globalisation in The 21st Century, 2nd ed. London: Sage. 
HePburn, MARY A., Richard G. NiEMI, AND Chris ChAPMAN. 2000. "Service Learning in College Political Science: Queries and Commentary." PS: Political Science \& Politics 33 (3): 617 622.

HESS, MARY E. 2011. “2010 Presidential Address: Learning Religion and Religiously Learning Amid Global Cultural Flows.” Religious Education 106 (4): 360-377.

Hobson, JoHn M., AND AlinA SAJED. 2017. "Navigating Beyond the Eurofetishist Frontier of Critical IR Theory: Exploring the Complex Landscapes of Non-Western Agency.” International Studies Review 19 (4): 547-572.

Hoffmann, Stanley. 1977. “An American Social Science: International Relations.” Daedalus 106 (3): 41-60.

Huntington, SAmuel P. 1993. “The Clash of Civilizations?” Foreign Affairs 72 (3): 22-49.

-----. 1996. The Clash of Civilizations and the Remaking of World Order. New York: Simon \& Schuster.

Hurd, Elizabeth Shakman. 2008. The Politics of Secularism in International Relations. Princeton, NJ: Princeton University Press.

JaCkSON, PAtrick Thaddeus. 2006. Civilizing the Enemy: German Reconstruction and the Invention of the West. Ann Arbor, MI: University of Michigan Press.

JAmal, Amaney A. 2007. Barriers to Democracy: The Other Side of Social Capital in Palestine and the Arab World. Princeton, NJ: Princeton University Press.

JUERGENSMEYER, MARK. 2008. Global Rebellion: Religious Challenges to the Secular State, from Christian Militias to al Qaeda. Berkeley, CA: University of California Press.

Kalawar, JayAnt. 2006. "Propagating Prejudices: Hinduism Studies in Schools of America." Manushi 155 (July-August): 12-17.

KAllis, ARISTOTLE, SARA ZEIGER, AND BILGEHAN ÖZTÜRK, EDS. 2018. Violent Radicalisation \& Far-Right Extremism in Europe. Ankara: SETA Publications.

Kartabayeva, Yerke, BakytKul Soltyeva, And Ainura Beisegulova. 2015. "Teaching Religious Studies as an Academic Discipline in Higher Education Institutions of Kazakhstan." Procedia-Social and Behavioral Sciences 214 (December): 290-296. 
Katzenstein, Peter J., ED. 2010. Civilizations in World Politics: Plural and Pluralist Perspectives. New York: Routledge.

KEPEL, GILLES. 1994. The Revenge of God: the Resurgence of Islam, Christianity and Judaism in the Modern World. Cambridge: Polity.

------. 2004. The War for Muslim Minds: Islam and the West. Cambridge, MA: Belknap Press of Harvard University Press.

Kettell, Steven. 2012. “Has Political Science Ignored Religion?” PS: Political Science \& Politics 45 (1): 93-100.

-----. 2016. “Do We Need a 'Political Science of Religion'?” Political Studies Review 14 (2): 210222.

KubÁLKOvÁ, VendulKa. 2000. "Towards an International Political Theology.” MillenniumJournal of International Studies 29 (3): 675-704.

Kuru, Ahmet T. 2009. Secularism and State Policies toward Religion: the United States, France, and Turkey. Cambridge: Cambridge University Press.

KurZman, Charles, And IJlal NaQVI. 2010. "Do Muslims Vote Islamic?” Journal of Democracy 21 (2): 50-63.

Laban Hinton, Alexander, Giorgio Shani, And Jeremiah Alberg, eds. 2019. Rethinking Peace: Discourse, Memory, Translation, and Dialogue. London: Rowman \& Littlefield.

LABORDE, CÉCILE. 2017. Liberalism's Religion. Cambridge, MA: Harvard University Press.

LAKE, DAVID A. 2016. “White Man's IR: An Intellectual Confession.” Perspectives on Politics 14 (4): 1112-1122.

LAWREnCE, BruCE B. 1989. Defenders of God: the Fundamentalist Revolt Against the Modern Age. San Francisco: Harper \& Row.

Lilla, Mark. 2007. The Stillborn God: Religion, Politics, and the Modern West. New York: Alfred Knopf.

LINKLATER, ANDREW. 2017. Violence and Civilization in the Western States-Systems. Cambridge: Cambridge University Press. 
Linklater, AndRew, And StePhen Mennell. 2010. "Norbert Elias, The Civilizing Process: Sociogenetic and Psychogenetic Investigations - An Overview and Assessment." History and Theory 49 (3): 384-411.

LOCKLIN, Reid B., TRACy TIEMEIER, AND Johann M. Vento. 2012. “Teaching World Religions Without Teaching 'World Religions.”' Teaching Theology \& Religion 15 (2): 159-181.

MandaVille, Peter. 2017. "The Future of Religion and U.S. Foreign Policy under Trump." Washington, DC: The Brookings Institution. Accessed July 30, 2018. https:/www.brookings.edu/research/the-future-of-religion-and-u-s-foreign-policy-under-trump/.

MandaVille, Peter, AND Melissa Nozell. 2017. "Engaging Religion and Religious Actors in Countering Violent Extremism - Special Report 413." Washington, DC: United States Institute of Peace. Accessed July 28, 2018. https://www.usip.org/sites/default/files/SR413-EngagingReligion-and-Religious-Actors-in-Countering-Violent-Extremism.pdf.

Marzouki, NADIA, DunCAN MCDONNEll, AND OliviER Roy, EDS. 2016. Saving the People: How Populists Hijack Religion. London: Hurst.

Mavelli, LuCA, AND Fabio Petito. 2012. "The Postsecular in International Relations: an Overview." Review of International Studies 38 (5): 931-942.

MenCHIK, JEREMY. 2017. "The Constructivist Approach to Religion and World Politics." Comparative Politics 49 (4): 561-581.

MoORE, DiAnE L. 2007. Overcoming Religious Illiteracy: A Cultural Studies Approach to the Study of Religion in Secondary Education, 1st ed. New York: Palgrave Macmillan.

NASH, ROBERT. 1998. Faith, Hype, and Clarity: Teaching About Religion in American Schools and Colleges. New York: Teachers College Press.

ORSI, ROBERT A. 2003. "Is the Study of Lived Religion Irrelevant to the World We Live In? Special Presidential Plenary Address, Society for the Scientific Study of Religion, Salt Lake City, November 2, 2002.” Journal for the Scientific Study of Religion 42 (2): 169-174.

-----. 2011. “Introduction.” In The Cambridge Companion to Religious Studies, edited by Robert A. Orsi, 1-14. Cambridge: Cambridge University Press.

PhilpotT, DANIEL. 2002. "The Challenge of September 11 to Secularism in International Relations." World Politics 55 (1): 66-95. 
-----. 2007. "Explaining the Political Ambivalence of Religion." American Political Science Review 101 (3): 505-525.

Prothero, StePhen R. 2007. Religious Literacy: What Every American Needs to Know--And Doesn't, 1st ed. San Francisco: Harper Collins.

SAID, EDWARD. 2001. "The Clash of Ignorance." The Nation, October 4. Accessed February 20, 2019. http://www.thenation.com/article/clash-ignorance.

SANDAL, NuKHET A. 2012. "The Clash of Public Theologies?: Rethinking the Concept of Religion in Global Politics.” Alternatives: Global, Local, Political 37 (1): 66-83.

-----. 2017. Religious Leaders and Conflict Transformation: Northern Ireland and Beyond. New York: Cambridge University Press.

SANDAL, NUKHET A., AND JONATHAN FOX. 2013. Religion in International Relations Theory: Interactions and Possibilities. Abingdon: Routledge.

SAyed, Yusuf, Lynn Davies, Mike Hardy, AbBas MAdANDAR ARANI, LidA KaKia, AND MASOODA BANO. 2011. "Global Security, Religion and Education Development: A Crisis for the Field of Comparative Education?” Compare 41 (3): 415-431.

SCHMitT, CARL. [1922] 1985. Political Theology: Four Chapters on the Concept of Sovereignty. Translated by George Schwab. Cambridge, MA: MIT Press.

Schwarz, TANYA B. 2018. "Teaching Religion, Conflict, and Peace.” Peace Review 30 (1): 3944.

SEN, AmARTYA. 2001. “A World Not Neatly Divided.” New York Times, November 23.

SHANI, GIORGIO. 2007. Sikh Nationalism and Identity in a Global Age. London: Routledge.

-----. 2008. "Toward a Post Western IR: The Umma, Khalsa Panth, and Critical International Relations Theory." International Studies Review 10 (4): 722-734.

-----. 2014. Religion, Identity and Human Security. London: Routledge.

-----. 2017. "Human Security as Ontological Security: a Post-colonial Approach.” Postcolonial Studies 20 (3): 275-293.

------. 2019. "Who Has Rights?" In Global Politics: a New Introduction, edited by Jenny Edkins and Maja Zehfuss, 524-545. London: Routledge. 
Shapiro, IAn, Rogers M. SMith, AND TAReK E. MASOUd, EDS. 2004. Problems and Methods in the Study of Politics, Vol. 28. Cambridge: Cambridge University Press.

Shellman, StePhen M., AND KÜRŞAD TURAN. 2006. "Do Simulations Enhance Student Learning? An Empirical Evaluation of an IR Simulation." Journal of Political Science Education 2 (1): 19-32.

Smith, Christian. 2017. Religion: What It Is, How It Works and Why It Matters. Princeton: Princeton University Press.

SMITH, CHRISTIAN, DAVID SIKKINK, AND JASON BAILEY. 1998. "Devotion in Dixie and Beyond: A Test of the 'Shibley Thesis' on the Effects of Regional Origin and Migration on Individual Religiosity." Journal for the Scientific Study of Religion 37 (3): 494-506.

Smith, Elizabeth T., AND Mark A. BOyer. 1996. "Designing In-Class Simulations." PS: Political Science \& Politics 29 (4): 690-694.

SNYDER, JACK, ED. 2011. Religion and International Relations Theory. New York: Columbia University Press.

STEPAN, AlfRed C. 2000. "Religion, Democracy, and the "Twin Tolerations." Journal of Democracy 11 (4): 37-57.

Stepan, Alfred C., AND Graeme B. Robertson. 2004. "Arab, Not Muslim, Exceptionalism.” Journal of Democracy 15 (4): 140-146.

TAYLOR, ChARLES. 2007. A Secular Age. Cambridge, MA: Harvard University Press.

TePe, Sultan, And Betul Demirkaya. 2011. “(Not) Getting Religion: Has Political Science Lost Sight of Islam?” Politics and Religion 4 (2): 203-228.

The Immanent Frame. 2017. “What are You Teaching?” Accessed December 14, 2018. https://tif.ssrc.org/2017/12/14/what-are-you-teaching/.

-----. 2018. “Teaching with The Immanent Frame." Accessed December 14, 2018. https://tif.ssrc.org/2018/09/20/teaching-with-the-immanent-frame/ - Deo.

ThOMAS, SCOTT. 2000. "Taking Religious and Cultural Pluralism Seriously: The Global Resurgence of Religion and the Transformation of International Society." Millennium-Journal of International Studies 29 (3): 815-841. 
-----. 2005. The Global Resurgence of Religion and the Transformation of International Relations: the Struggle for the Soul of the Twenty-first Century. Basingstoke: Palgrave Macmillan.

Toft, Monica Duffy, Daniel Philpott, AND Timothy SAmuel Shah. 2011. God's Century: Resurgent Religion and Global Politics. New York: W.W. Norton.

VAN DOORN-HARDER, Nelly. 2007. "Teaching Religion in the USA: Bridging the Gaps." British Journal of Religious Education 29 (1): 101-113.

VAn Evera, StePhen. 2010. "Director's Statement: Trends in Political Science and the Future of Security Studies.” MIT Security Studies Program: Annual Report 2009-2010. Accessed March 20, 2019. http://web.mit.edu/SSP/publications/annual/ssp_annual_report2010.pdf.

Wiktorowicz, Quintan. 2006. "Anatomy of the Salafi Movement." Studies in Conflict \& Terrorism 29 (3): 207-239.

WilcoX, Clyde, AND CARIN LARSOn. 2006. Onward Christian Soldiers?: the Religious Right in American Politics. Boulder, CO: Westview Press.

ZuBAIDA, SAMI. 2009. "Political Modernity." In Islam and Modernity: Key Issues and Debates, edited by Muhammad Khalid Masud, Armando Salvatore, and Martin van Bruinessen, 57-88. Edinburgh: Edinburgh University Press. 